\title{
ANALISIS PERANCANGAN PRODUK ALAT PENCETAK SPASI SEMEN BATU BATA UNTUK MENINGKATKAN PRODUKTIVITAS (Studi Kasus: CV. Mangku Putra)
}

\author{
FRANS JR \\ Program Studi Teknik Industri Universitas Katolik Musi Charitas \\ Jl. Bangau No. 60, Palembang 30113 \\ E-mail: Fransj871@gmail.com
}

\begin{abstract}
One way to deal with it is by product development that is to make improvements, improvements or produce new products that are different from existing products. The new Product Development strives to simplify the work in effective and efficient ways. In the process of building a house there is a wall-mounting activity where the bricks are arranged with the help of cement to paste the bricks that are aimed at the brick well-arranged, but in the use of cement often seen the cement used to fall apart to the side of the brick. The process of designing and developing a product is done using a rational method that has several steps. The steps in the rational method are: Clarifying Objectives, Establishing Function, Setting Requirements, Determining Characteristics, Generating Alternatives, Evaluating Altenatives, Improving Details. In this study the authors aim to get the design of bricks spacing tool to improve the performance of artisans and improve the quality of the process that includes the skills of artisans and improve the efficiency of raw materials by testing product design and product development made by the author by comparing the data processing time before and after implementation using the help software SPSS 16.00. Result of t test by using software SPSS 16.00 got result that using tool better design in time and productivity of use of raw materials using tool design increase. Result from before using tool got productivity 40,677 after menggguakan tool got produktiviyas 42,105
\end{abstract}

Keywords: Product Design and Development, Efficiency, Rational Method

\section{PENDAHULUAN}

Dalam rangka menghadapi era globalisasi dan era persaingan baik secara nasional maupun internasional yang semakin ketat. Pihak pesaing akan selalu berusaha dengan sekuat tenaga untuk memenuhi keinginan konsumen. Mereka berusaha agar produknya lebih unggul dari produk pesaing.

Salah satu cara untuk menghadapi hal-hal tersebut diatas adalah dengan pengembangan produk yaitu melakukan perbaikan, penyempurnaan atu menghasilkan produk baru yang berbeda dengan produk yang telah ada.

Dengan demikian waktu kerja adalah benar - benar menentukan biaya, semakin panjang waktu yang digunakan semakin besar biaya yang dikeluarkan. 


\section{Jurnal TEKNO}

(Civil Engineeering, Elektrical Engineeering and Industrial Engineeering)

Vol. 16, No : 1, April 2019 , p-ISSN:1907-5243, e-ISSN: 2655-8416

Waktu kerja ditentukan oleh produktivitas dari kelompok kerja dalam mengerjakan proyek konstruksi, maka untuk itulah penelitian ini perlu dilakukan, karena akan menghasilkan produktivitas kelompok kerja dalam mengerjakan proyek konstruksi serta akan mengetahui faktor - faktor apa saja yang berpengaruh terhadap efisiensi.

Berdasarkan hasil pengamatan yang diambil pada CV. Mangku Putra diketahui bahwa pekerjaan memasang dinding batu bata mengalami masalah. Untuk membuat rumah tipe 36 memerlukan bahan baku semen kurang lebih sebanyak 79 sak $(50 \mathrm{~kg}$ ), batu bata sebanyak 19.320 buah (dengan ukuran bata, panjang $24 \mathrm{~cm}$, lebar $11,5 \mathrm{~cm}$ dan tinggi $5,2 \mathrm{~cm}$ ) dan menggunakan pasir $11 \mathrm{~m}^{3}$ dengan takaran campuran 1 semen : 3 pasir. Sedangkan CV. Hutama Karya untuk membangun rumah dengan tipe yang sama yaitu tipe 36 dibutuhkan semen sebanyak 78 sak semen, dengan jumlah batu bata yang relatif sama dengan jumlah batu bata yang relatif sama dan untuk data waktu tidak terdapat perbedaan yang signifikan. Dari perbandingan tersebut terdapat selisih 1 sak untuk membangun rumah tipe 36. Hasil pengamatan menunjukkan bahwa saat pekerja melakukan pemasangan dinding tersebut, semen yang dituang tidak tertata rapi sehingga memerlukan waktu yang cukup lama untuk meratakan semen. Rancangan alat yang akan dibuat mengggunakan data tentang kerja tukang dan bahan baku. Oleh karena itu perlu dilakukan alat perancangan guna meminimalisir penggunaan bahan baku yang terbuang dan tidak mengganggu kinerja tukang. Pada penelitian ini perancangan alat akan menggunakan metode rasional dengan harapan dapat meningkatkan tingkat efektivitas kerja pada tukang dan membuat efisiensi semen yang tersusun diatas batu bata tersusun rapi. Adapun metode yang digunakan dalam penelitian ini yaitu Metode Perancangan Rasional.

Masalah yang dihadapi dalam penelitian adalah bagaimana perbaikan merancang suatu alat pencetakspasi semen pada batu bataguna meminimalisir bahan baku terbuang?

Tujuan Penelitian ini adalah : (1) Mendapatkan rancangan alat pencetak spasi batu bata, (2) Meningkatkan efisiensi bahan baku dan (3) meningkatkan kerapian kerja tukang.

Untuk mendapatkan hasil penelitian yang spesifik dan terarah, maka ruang lingkup dari penelitian ini adalah (1) penelitian ini hanya berfokus pada proses pemasangan dinding dan (2) penelitian ini berfokus pada perancangan dan pengembangan produk.

Peneliti yang pernah mengambil penilitian tentang perancangan dan pengembangan produk adalah:

1. Analisis Pengembangan Produk Dalam Meningkatkan Produktivitas Pembuatan Sepatu Kulit FINALDO (Studi Kasus Industri Sepatu Kulit Finaldo Suwaduk Wedarijaksapati).[1]

2. Perancangan Alat Pengupas Kulit Lunak Melinjo yang Ergonomis dengan Pendekatan Metode Rasional Untuk Meningkatkan Produktivitas Produksi.[2] 


\section{Jurnal TEKNO}

(Civil Engineeering, Elektrical Engineeering and Industrial Engineeering)

Vol. 16, No : 1, April 2019 , p-ISSN:1907-5243, e-ISSN: 2655-8416

\section{METODE}

\subsection{Perancangan Produk}

Tiga hal yang harus diperhatikan dalam perancangan yaitu :

a. Aktivitas dengan maksud tertentu,

b. Sasaran pada pemenuhan kebutuhan manusia dan

c. Berdasarkan pada pertimbangan teknologi.

Proses perancangan yang merupakan tahapan umum teknik perancangan dikenal dengan sebutan $N I D A$, yang merupakan kepanjangan dari Need, Idea, Decision dan Action. Artinya tahap pertama seorang perancang menetapkan dan mengidentifikasi kebutuhan. Sehubungan dengan alat atau produk yang harus dirancang. Kemudian dilanjutkan dengan pengembangan ide-ide (idea) yang akan melahirkan berbagai alternatif untuk memenuhi kebutuhan tadi dilakukan suatu penilaian dan penganalisaan terhadap berbagai alternatif yang ada, sehingga perancang akan dapat memutuskan (decision) suatu alternatif yang terbaik. Dan pada akhirnya dilakukan suatu proses pembuatan (Action). Perancangan suatu peralatan kerja dengan berdasarkan data antropometri pemakainya betujuan untuk mengurangi tingkat kelelahan kerja, meningkatkan performansi kerja dan meminimasi potensi kecelakaan kerja. [3]

\subsection{Produktivitas}

Produktivitas tidak sama dengan produksi, tetapi produksi, performansi kualitas, hasil-hasil, merupakan komponen dari usaha produktivitas. Dengan demikian, produktivitas merupakan suatu kombinasi dari efektivitas dan efisiensi, sehingga produktivitas dapat diukur.[4]

Input $=\frac{\text { VolumePemakaianBahanBaku }}{\text { VoumeBahanBakuTersedia }}$

Produktivitas $=\frac{\text { Output yang dihasilkan }}{\text { Input yang dipergunakan }}=\frac{\text { Efektivitas }}{\text { Efisiensi }}$

\subsection{Metode Perancangan Rasional}

Clarifying Objectives dimana langkah ini menjelaskan mengenai tujuan perancangan. Metode yang digunakan adalah objectives tree. Metode ini bertujuan untuk menjelaskan tujuan dan sub tujuan dari perancangan dan hubungan diantara keduanya. Langkah-langkah pembuatan objectives tree adalah sebagai berikut: [5]

a. Menyiapkan daftar tujuan perancangan. Daftar ini diambil dari ringkasan perancangan, dari pernyataan kepada klien dan dari diskusi didalam kelompok perancangan. 


\section{Jurnal TEKNO}

(Civil Engineeering, Elektrical Engineeering and Industrial Engineeering)

Vol. 16, No : 1, April 2019 , p-ISSN:1907-5243, e-ISSN: 2655-8416

b. Daftar disusun ke dalam kumpulan tujuan tingkat tinggi dan tingkat rendah. Perluasan daftar tujuan dan sub tujuan secara kasar dapat dikelompokkan ke dalam tingkatan hirarki.

c. Menggambarkan diagram Objectives Tree, hubungan hirarki dan garis hubungannya. Cabang-cabang atau akar dalam pohon menggambarkan hubungan yang mengusulkan bagaimana mencapai tujuan

Establishing Function Metode analisis fungsi ini menawarkan fungsifungsi penting dan level dari masalah yang ada. Metode ini bertujuan untuk menentukan fungsi yang dibutuhkan dan batasan sistem dari perancangan baru. Prosedur-prosedur dari metode ini adalah:

a. Menjelaskan seluruh fungsi perancangan dalam perubahan input menjadi output.

b. Memecah seluruh fungsi menjadi sub-fungsi dasar.

c. Menggambarkan diagram blok yang menggambarkan interaksi antar subfungsi.

d. Menggambarkan batas system.

e. Mencari komponen yang tepat untuk menampilkan subfungsi dan interaksinya.

Setting Requirements Metode yang digunakan adalah The Performance Specification Methods. Metode ini bertujuan membantu menemukan masalah perancangan. Langkah-langkah metode ini adalah sebagai berikut :

a. Menimbang perbedaan tingkatan umum penyelesaian yang dapat diterima. Misal ada beberapa pilihan alternatif produk, tipe produk dan ciri-ciri produk.

b. Menentukan tingkatan umum yang nantinya akan dioperasikan. Keputusan ini biasanya dibuat oleh konsumen. Tingkatan umum yang lebih tinggi memberikan kebebasan yang lebih untuk perancangan.

c. Mengidentifikasi atribut yang dibutuhkan. Atribut harus dinyatakan secara bebas untuk solusi tertentu.

d. Menyebutkan persyaratan yang diperlukan atribut dengan tepat danteliti. Bila dimungkinkan, spesifikasi harus dalam bentuk kuantitatif dan mengidentifikasikan jarak antar batas.

Determining Characteristics Tujuannya untuk menetapkan target yang akan dicapai oleh karakteristik teknis produk yang dapat memenuhi keinginan konsumen :

a. Mengidentifikasikan keinginan konsumen terhadap atribut produk. Suara konsumen dihargai dan keinginan konsumen bukan merupakan subjek untuk diterjemahkan oleh tim desain.

b. Menentukan atribut yang relatif penting Teknik pemberian rangking atau penempatan nilai dapat digunakan untuk membantu menentukan bobot relatif yang harus didampingkan dengan berbagai atribut. Persentase bobot normal digunakan. 


\section{Jurnal TEKNO}

(Civil Engineeering, Elektrical Engineeering and Industrial Engineeering) Vol. 16, No : 1, April 2019 , p-ISSN:1907-5243, e-ISSN: 2655-8416

c. Mengevaluasi atribut terhadap produk pesaing Nilai performansi untukproduk pesaing dan produk hasil rancangan tim desain harus terdaftar pada keinginan konsumen.

d. Menggambar matrik atribut produk dalam karakteristik teknik termasuk semua karakteristik teknik yang mempengaruhi sejumlah atribut produk dan memastikannya untuk dapat disampaikan dalam unit-unit yang dapat diukur.

e. Mengidentifikasi hubungan antara karakteristik teknik dengan atribut produk Kekuatan hubungan dapat diidentifikasikan dengan simbol atau nomor, penggunaan nomor mempunyai beberapa keuntungan, tetapi dapat memperkenalkan sebuah keakuratan palsu.

f. Mengidentifikasi beberapa hubungan yang relevan antara karakteristik teknik Atap rumah dari House of Quality menguntungkan pengecekan, tetapi tergantung terhadap perubahan dalam konsep desain.

g. Mengatur target figur yang dapat dicapai untuk karakteristik teknik Menggunakan informasi dari produk pesaing atau percobaan dengan konsumen-konsumennya

Generating Alternatives Pada tahap ini mulai dicari solusi-solusi yang mungkin.Metode yang bisa dipakai adalah Morphological Chart Method. Morphological chart ini berguna untuk memperluas daerah pencarian solusi baru yang potensial dalam pengembangan alternatif. Kombinasi yang berbeda dari dari sub solusi dapat dipilih dari morphological chart, dan diharapkan dapat memunculkan solusi baru yang belum pernah teridentifikasi sebelumnya. Langkah-langkah pembuatan morphological chart adalah sebagai berikut

a. Membuat daftar fitur atau fungsi yang penting untuk produk tersebut.

b. Membuat daftar cara-cara untuk setiap fitur atau fungsi tersebut.

c. Menggambarkan bagan yang memuat seluruh solusi yang memungkinkan terjadi.

d. Mengidentifikasi kombinasi sub-solusi yang memungkinkan.

Evaluating Alternatives Tahap ini adalah tahap pemilihan alternatif terbaik diantara beberapa alternatif yang ada. Metode yang digunakan adalah metode weighted objectives (pembobotan obyektif).

a. Membuat daftar tujuan perancangan. Pohon objektif dapat juga sebagai tambahan berguna untuk metode ini.

b. Mengurutkan tingkatan tujuan. Perbandingan dapat membantu menyusun urutan tingkatan.

c. Menentukan pembobotan relatif tujuan.

d. Menyusun nilai kegunaan untuk setiap tujuan.

e. Menghitung dan membandingkan nilai kegunaan relatif perancangan alternatif.

Improving Details Tujuan utamanya adalah untuk meningkatkan fungsi atau nilai produk dan mereduksi biaya produksi. Beberapa tahapan yang perlu dilakukan dalam teknik value engineering adalah : 


\section{Jurnal TEKNO}

(Civil Engineeering, Elektrical Engineeering and Industrial Engineeering)

Vol. 16, No : 1, April 2019 , p-ISSN:1907-5243, e-ISSN: 2655-8416

a. Pembuatan daftar komponen-komponen produk, identifikasi fungsi dari setiap komponen.

b. Pembandingan nilai dari setiap fungsi yang telah diidentifikasi (nilai disini adalah nilai yang dirasakan oleh konsumen).

c. Pembandingan biaya dari setiap komponen (setelah komponen selesai dirakit).

d. Pencarian solusi untuk pengurangan biaya tanpa pengurangan performansi/nilai fungsional produk atau penambahan performansi/nilai fungsional produk tanpa penambahan biaya. Dalam hal perlu adanya suatu teknik kreatif yang kritis.

e. Pengevaluasian alternatif dan pemilihan pengembangan yang dilakukan.

\section{HASIL DAN PEMBAHASAN}

\subsection{Tahapan Clarifying Objectives}

Clarifying Objectives dimana langkah ini menjelaskan mengenai tujuan perancangan. Metode yang digunakan adalah objectives tree. Metode ini bertujuan untuk menjelaskan tujuan dan sub tujuan dari perancangan dan hubungan diantara keduanya

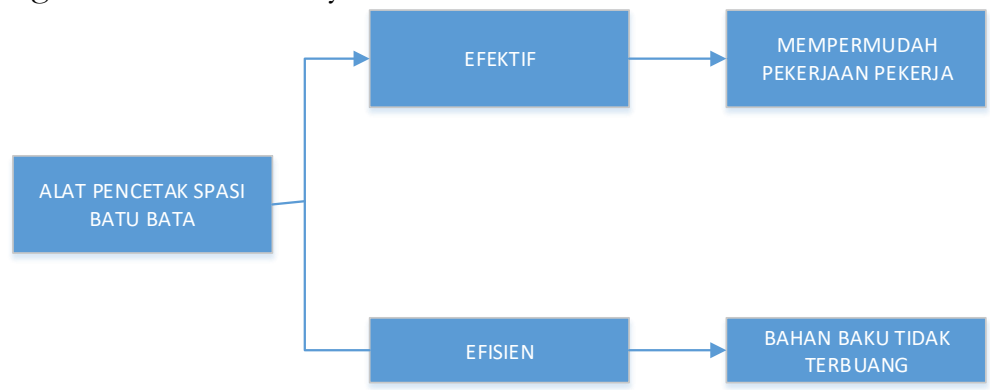

Gambar 1 Objective Tree Alat Pencetak Spasi Batu Bata

\subsection{Tahapan Establishing Functions}

Metode analisis fungsi ini menawarkan fungsi-fungsi penting dan level dari masalah yang ada. Metode ini bertujuan untuk menentukan fungsi yang dibutuhkan dan batasan sistem dari perancangan baru

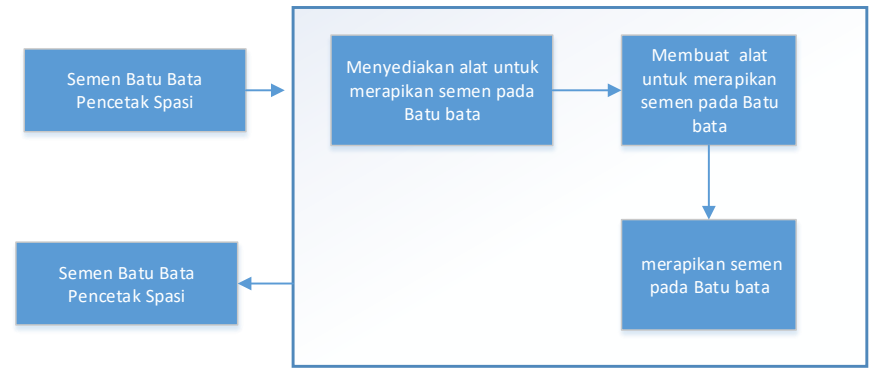




\section{Jurnal TEKNO}

(Civil Engineeering, Elektrical Engineeering and Industrial Engineeering)

Vol. 16, No : 1, April 2019 , p-ISSN:1907-5243, e-ISSN: 2655-8416

\subsection{Tahapan Setting Requirements}

Pada tahap ini metode yang digunakan yaitu spesifikasi performansi (performance specification). Metode ini bertujuan untuk membuat spesifikasi yang akurat dari kebutuhan pelaksanaan suatu perancangan alat pencetak spasi pada batu bata. Performansi spesifikasi untuk perancangan alat pemotong kertas dapat dilihat pada table 4.4 berikut ini :

Tabel 1 Spesifikasi Performansi Perancangan Alat

\begin{tabular}{lll}
\hline No & \multicolumn{1}{c}{ Tujuan } & \multicolumn{1}{c}{ Kriteria } \\
\hline $\mathbf{1}$ & $\begin{array}{l}\text { Meminimalisir penggunaan bahan baku } \\
\text { terbuang }\end{array}$ & a. $\begin{array}{l}\text { Bahan baku yang } \\
\text { digunakan dapat terbuat } \\
\text { dari besi, aluminium }\end{array}$ \\
& b. $\begin{array}{l}\text { Ukuran alat disesuaikan } \\
\text { dengan ukuran batu bata } \\
\text { yang digunakan }\end{array}$ \\
$\mathbf{2}$ & Meningkatkan tingkat kerapihan & $\begin{array}{l}\text { Tingkat kerapihan pada pekerjaan } \\
\text { pemasangan batu bata menjadi } \\
\text { lebih rapih }\end{array}$ \\
\hline
\end{tabular}

\subsection{Tahapan Determining Characteristics}

- Tahapan ini berisi tentang target yang akan dicapai dari setiap karakteristik produk sehingga tujuan penelitian dapat terjawab. karena pada penelitian ini difokuskan pada karateristik teknis alat, yaitu perancangan alat pencetak spasi batu bata untuk menghasilkan dinding yang lebih rapi.

Tabel 2. Hasil Pengukuran

\begin{tabular}{ccc}
\hline No. & Nama Pekerja & Jarak Rentangan Tangan $(\mathbf{c m})$ \\
\hline $\mathbf{1 .}$ & Kasiman & 124 \\
\hline $\mathbf{2 .}$ & Subianto & 126 \\
$\mathbf{3 .}$ & Warisito & 123 \\
$\mathbf{4 .}$ & Bayu & 130 \\
$\mathbf{5 .}$ & Damar & 127 \\
\multicolumn{2}{c}{ Rata-rata } & 126 \\
\hline
\end{tabular}

\subsection{Tahapan Generating Alternatives}

Tahapan Generating alternatives menggunakan peta morfologi (Morphological Chart). Peta ini memiliki tujuan untuk menyusun secara lengkap bagian-bagian 


\section{Jurnal TEKNO}

(Civil Engineeering, Elektrical Engineeering and Industrial Engineeering) Vol. 16, No : 1, April 2019 , p-ISSN:1907-5243, e-ISSN: 2655-8416

dari perancangan alat pencetak spesi batu bata serta bahan alternative yang dapat digunakan. Berikut adalah Peta Morfologi untuk alat pencetak spesi batu bata:

Tabel 3 Peta Morfologi Alternatif Bahan

\begin{tabular}{lccc}
\hline \multicolumn{1}{c}{ Atribut } & \multicolumn{3}{c}{ Alternatif } \\
\cline { 2 - 4 } Bahan Kerangka & 1 & 2 & 3 \\
Bahan Perata Semen & Besi & Stainless steel & Aluminium \\
\hline
\end{tabular}

Tabel 4 Peta Morfologi Alternatif Bahan

\begin{tabular}{lccc}
\hline \multicolumn{1}{c}{ Atribut } & \multicolumn{3}{c}{ Alternatif } \\
\cline { 2 - 4 } Bahan Kerangka & 1 & 2 & 3 \\
Bahan Perata Semen & Gergaji Besi & Mesin Gerinda & Mesin Las \\
\hline
\end{tabular}

3.6. Tahapan Evaluating

Tabel 4 Alternatives Perbandingan bahan baku

\begin{tabular}{|c|c|c|}
\hline Bahan & Kelebihan & Kekurangan \\
\hline Besi Plat & $\begin{array}{ll}\text { - } & \text { Mudah dibentuk } \\
\text { - } & \text { Kuat } \\
\text { - } & \text { Tahan air }\end{array}$ & $\begin{array}{l}\text { - Harga relative lebih } \\
\text { mahal }\end{array}$ \\
\hline Besi hollow & $\begin{array}{ll}\text { - } & \text { Harga lebih } \\
\text { murah } \\
\text { - } \quad \text { Lebih ringan } \\
\text { - } \quad \text { Di bongkar } \\
\text { pasang }\end{array}$ & $\begin{array}{ll}\text { - } & \text { Kurang kuat } \\
\text { - } & \text { Ukuran besi } \\
& \text { hollow }\end{array}$ \\
\hline Stainless steel & $\begin{array}{ll}\text { - } & \text { Tidak berkarat } \\
\text { - } & \text { Tidak mudah } \\
& \text { pecah } \\
\text { - } & \text { Ringan bawa }\end{array}$ & - Harga relatif mahal \\
\hline
\end{tabular}




\section{Jurnal TEKNO}

(Civil Engineeering, Elektrical Engineeering and Industrial Engineeering)

Vol. 16, No : 1, April 2019 , p-ISSN:1907-5243, e-ISSN: 2655-8416

Tabel 5. Kelebihan dan Kekurangan Perbandingan Alat yang digunakan

\begin{tabular}{|c|c|c|}
\hline Alat & Kelebihan & Kekurangan \\
\hline Gergaji Mesin & 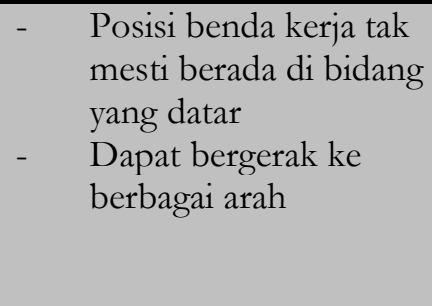 & $\begin{array}{ll}\text { - } & \text { Membutuhkan waktu } \\
\text { yang lama jika } \\
\text { melakukan kegiatan } \\
\text { berulang } \\
\text { - Mata pisau mudah patah } \\
\text { - Tidak dapat } \\
\text { menghaluskan potongan }\end{array}$ \\
\hline Mesin Gerinda & 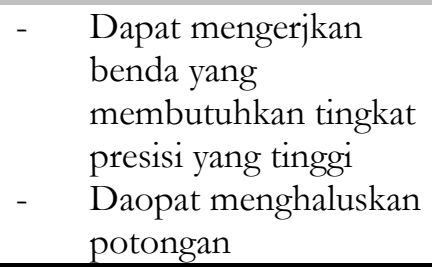 & $\begin{array}{l}\text { - Waktu yang dibutuhkan } \\
\text { cukup lama } \\
\text { - Skala bentuk alat yang di } \\
\text { potong terbatas }\end{array}$ \\
\hline
\end{tabular}

3.7. Gambar Rancangan Alat

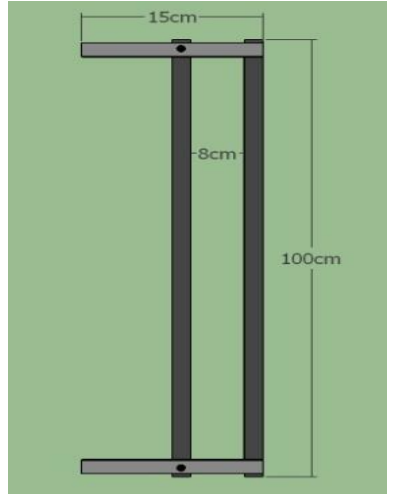

(a)

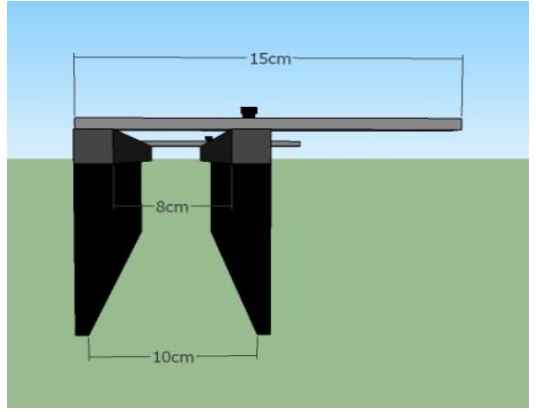

(b)

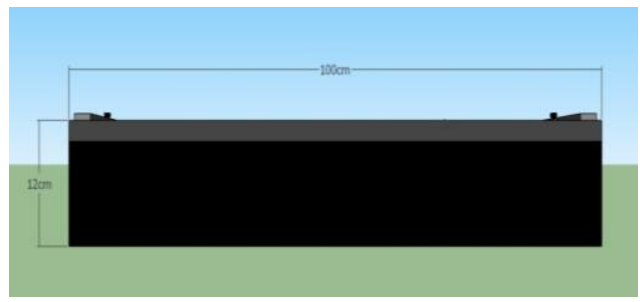

(c)

Gambar 2 (a) Tampak Atas, (b) tampak depan dan (c) tampak samping 


\section{Jurnal TEKNO}

(Civil Engineeering, Elektrical Engineeering and Industrial Engineeering)

Vol. 16, No : 1, April 2019 , p-ISSN:1907-5243, e-ISSN: 2655-8416

3.8. Pengukuran Produktivitas Sebelum Menggunakan alat

Luas tembok yang akan dibangun : $6 \times 4=24 \mathrm{~m}^{2}$

Jumlah semen yang tersedia $\quad: 5 \mathrm{sak}$

Jumlah pasir yang tersedia $\quad: 2 \mathrm{~m}^{3}=2000 \mathrm{~kg}$

Pemakaian semen $\quad: 10 \mathrm{~kg}$

Pemakaian pasir $\quad: 0,045 \mathrm{~m}^{3}$

Input $=\frac{\text { VolumePemakaianBahanBaku }}{\text { VolumeBahanBakuTersedia }}$

Input $=\frac{(24 \times 10)+(0,045 \mathrm{~m} 3 \times 24)}{(5 \times 50)+2000 \mathrm{~kg}}=\frac{240+1080}{2.250 \mathrm{~kg}}$

Input $=\frac{1320 \mathrm{~kg}}{2.250 \mathrm{~kg}}=0,59$

Produktivitas $=\frac{24}{0,59}=40,677$

3.9. Pengukuran Produktivitas Setelah Menggunakan alat

Luas tembok yang akan dibangun : $6 \times 4=24 \mathrm{~m}^{2}$

Jumlah semen yang tersedia $\quad: 5 \mathrm{sak}$

Jumlah pasir yang tersedia $\quad: 2 \mathrm{~m}^{3}=2000 \mathrm{~kg}$

Pemakaian semen $\quad: 9 \mathrm{~kg}$

Pemakaian pasir $\quad: 0,045 \mathrm{~m}^{3}$

$$
\begin{aligned}
& \text { Input }=\frac{\text { VolumePemakaianBahanBaku }}{\text { VoumeBahanBakuTersedia }} \\
& \text { Input }=\frac{\text { VolumePemakaianBahanBaku }}{(5 \times 50)+2000 \mathrm{~kg}} \\
& \text { Input }=\frac{(24 \times 9)+(0,045 \mathrm{~m} 3 \times 24)}{(5 \times 50)+2000 \mathrm{~kg}} \\
& \text { Input }=\frac{1296}{2.250 \mathrm{~kg}}=0,57
\end{aligned}
$$

Produktivitas $=\frac{24}{0,57}=42,105$ 


\section{Jurnal TEKNO}

(Civil Engineeering, Elektrical Engineeering and Industrial Engineeering)

Vol. 16, No : 1, April 2019 , p-ISSN:1907-5243, e-ISSN: 2655-8416

\section{KESIMPULAN}

Setelah melakukan tahapan dalam mengumpulkan dan mengolah data pada pekerja yang bekerja di CV. Mangku Putra maka dapat disimpulkan:

1. Perancangan alat pencetak spesi batu bata sesuai dengan ukuran batu bata yang gunakan tukang untuk membangun dinding. Adapun ukuran dari alat pencetak spesi batu bata yaitu memiliki panjang $126 \mathrm{~cm}$ dengan lebar alat dapat mencapai $14 \mathrm{~cm}$, dan ketinggian alat $7 \mathrm{~cm}$.

2. Dengan adanya alat pencetak spasi batu bata yang baru ini memiliki peningkatan produktivitas dalam meminimalisir bahan pada waktu proses pemasangan batu bata. Hal ini ditunjukkan dengan waktu rata-rata waktu proses pemasangan batu bata sebelum implementasi adalah 51,7 menit sedangkan setelah menggunakan alat rata-rata waktu proses pemasangan menjadi 49,3, dan jika melihat dari produktivitas ada terjadinya peningkatan produktivitas parsial yang sebelum implementasi menunjukkan hasil 0,59 sedangkan setelah implementasi menunjukkan hasil 0,57 .

\section{Saran}

Setelah melakukan penelitian ini, adapun saran yang dapat diberikan yaitu sebaiknya para pekerja yang bekerja di CV. Mangku Putra yang bertugas membuat rumah memiliki alat pencetak spesi batu bata guna untuk meminimalisir biaya yang dikeluarkan akibat penggunaan bahan baku.

\section{DAFTAR PUSTAKA}

[1] Zahroh, Fatimatuz (2016) Analisis Pengembangan Produk Dalam Meningkatkan Produktivitas Pembuatan Sepatu Kulit Di Industri Sepatu Kulit Finaldo Suwaduk Wedarijaksa Pati. Skripsi Thesis, Stain Kudus.

[2] Safarudin Ramdhani (2014)Perancangan Alat Pengupas Kulit Lunak Melinjo Yangergonomis Dengan Pendekatan Metode Rasional Untukmeningkatkan Produktivitas Produksi Program Studi Teknik Industri - S1, Fakultas Teknik,Universitas Dian Nuswantoro Semarang

[3] Pulat, Babur Mustafa and Alexander, David C. editor. 1992, Industrial Ergonomics Case Studies. New York: Mc Graw-Hill,Inc.

[4] Sinungan, Muchtar. 2003. Produktivitas: Apa dan Bagaimana. Jakarta: Bumi Aksara

[5] Cross, N, 1994, Engineering Design Methods Strategies for Product Design, Edisi 2, John Wiley and Sons LTD, United Kingdom 